\title{
Students' Problems in Reading Narrative Text
}

\author{
Muhammad Firdi Yuvirawan ${ }^{1 *}$ Rina Listia ${ }^{1}$ Rizky Amelia ${ }^{1}$ \\ ${ }^{1}$ Lambung Mangkurat University, Indonesia \\ ${ }^{*}$ Corresponding author. Email: a1b215020@mhs.ulm.ac.id
}

\begin{abstract}
Reading is important on every level of education; however, it is not all students success at reading. The troubles that they face are critical to discover. Hence, this investigation under this research aims to find the understudies' issues in story text reading. The researchers employed a qualitative approach with descriptive method. The setting was at SMPN 2 Kandangan. A number of 59 eighth grade students were involved in this study. The data were collected by using a questionnaire, interview and a reading comprehension test. It is revealed that almost all participants face problems in reading narrative text. The problems are determining main ideas, finding detailed information, making inference, identifying reference, and understanding meaning of words. The researchers suggested the English teacher to utilize cooperative learning strateg and teach technique to find vocabulary meaning by using clues.
\end{abstract}

Keywords: Reading, Reading Comprehension, Student's Problems in Reading

\section{INTRODUCTION}

Reading is an important skill in education [1,2]. "Reading involves an awareness of contents. It is a complex movement involving recognition and thought" $[3,10]$. In reading, there are many obstacles and one of which is reading comprehension. Nearly all learning practices of students comprehend texts. Reading is not just looking at the text without comprehending it. Therefore, it is obvious that the need for reading comprehension ability is important [7].

In reading, there are many types of text genres learnt by students especially for junior high school that are relevant to the curriculum such as: narrative, descriptive, exposition, procedure, report and analytical. One of the texts is narrative. Furthermore, it can be fairy stories, parable, folktales, moral tales, myth, and legend [6,9]. Based on the previous study by Reference [4] about the ability of students to understand narrative text, the students were still susceptible to learning understanding. They were vulnerable to orientation, complication, resolution, reorientation, and vocabulary. Reference [2] study about reading comprehension issues confluence by nonnative speaker students in Albania, Croatia showed seven issues faced by way of the students namely 1) New words 2) Context information 3) Form of text 4) Structure 5) Lack of illustration 6) Tenses 7) Connecting words [8]. Meanwhile, Reference [1] have identified problems with students' reading comprehension, where they encounter vague words, unknown language, and are restricted to having time to cognitively technical text.

Based on the data of the theory and previous studies above, this study aims at completing the previous studies as it will be conducted at one of the Junior High Schools in Kalimantan Selatan provinces. As the information given by the English teacher from SMPN 2 Kandangan, the students of the eighth grade are excited if the topic that would be learnt is about stories. However, the score of the daily tests students in reading tests related to Narrative text material is under minimal completeness criteria or Kriteria Ketuntasan Minimal (KKM), 27 of 65 students get minimal completeness criteria. From this case, the researcher focuses on discovering what are students' problems in reading narrative text at the eighth grade students of SMPN 2 Kandangan in the academic year 2019/2020.

\subsection{Study Significances}

a. This study is useful to find students' problems in reading narrative text at eighth grade of SMPN 2 Kandangan in the academic year 2019/2020.

b. This study can give information about the problems faced by the students' particularly in reading narrative text.

c. This study can be used as references for the next researchers who are interested in the same field.

\subsection{Study Scopes}

a. The subjects of this study are the students' eighth grade of SMPN 2 Kandangan in the academic year 2019/2020. The location of this study is at SMPN 2 Kandangan Jalan Aluh Idut, Kandangan Kota, Kab. Hulu Sungai Selatan.

b. The study focuses on the difficulty students encounter while reading narrative texts

\section{METHOD}

\subsection{Research Approach and Design}

This study employed descriptive study and the approach is qualitative. It tried to describe phenomena about the students' problems in reading narrative text at the eighth grade of SMPN 2 Kandangan. Through this descriptive study, the researcher wants to find the students' problems in reading narrative text. The research setting of this study was held at junior high school 2 Kandangan, Aluh Idut Street, 
Kandangan Town, Hulu Sungai Selatan Regency. Indonesia. In this study the subjects were the eighth grades of the students of SMPN 2 Kandangan in the academic year $2019 / 2020$. The total number of the subject in this study was 59 students.

\subsection{The Instruments}

The questionnaire in this study was used to gather data of the problems that are faced by students of the eighth grade of SMPN 2 Kandangan in reading comprehension. The items of the questionnaire consist of 22 questions in which each question has four options to be chosen by respondents. The interview was used to know the effectiveness of the actions. The researcher interviews the English teacher and the students. The reading comprehension test was used to check the correctness of the data result from questionnaires and interview questions. The researcher used multiplechoice test. The tests consist of five narrative texts with 25 multiple-choice questions which have four choices of each.

Table 1 Reading Comprehension Test

\begin{tabular}{|c|c|}
\hline The Questions & Items Number \\
\hline Finding Main Idea & $5,6,11,16$, and 21 \\
\hline Finding Detailed Information & $1,7,12,17$, and 22 \\
\hline Making Inference & $3,8,13,20$, and 23 \\
\hline Identifying Reference & $2,10,15,18$, and 24 \\
\hline Understanding Meaning of Words & $4,9,14,19$, and 25 \\
\hline
\end{tabular}

In accumulating the data, the data was analyzed by using descriptive with a qualitative approach. The researcher gathered the data using the questionnaire, interview and a reading comprehension test. In using the questionnaire, the researchers asked 22 questions to the students' eighth grade to find the data. All the data were analyzed to describe the students' problems in reading narrative text and in using interview, the researchers asked questions relate to students' problem in reading narrative text to the English teacher and the students' the eighth grade of SMPN 2 Kandangan. The researchers also used a reading comprehension test to triangulate the data results from the questionnaire and the interview.

\subsection{Data Analysis}

The questionnaires are designed to identify the problems that students encounter when reading Narrative text and the data from the questionnaires were analyzed by using a descriptive qualitative method. The researchers classified students' answers, how many students choose A's answer, B's answer, C's answer and D's answer on the questions that are given. Then, researchers analyzed their answers in making conclusions based on the questions that they had answers.

The researchers asked the English teacher and the students' the eighth grade of SMPN 2 Kandangan about students' problems in reading narrative text at eighth grade. After that the researchers tried to discover what students' main problems are in reading narrative text at the eighth grade based on interview results. The reading comprehension test was used to check the correctness of the data result from questionnaires and interview questions. After the researchers found the data from the questionnaire and the interview, the researchers also gave a reading comprehension test to the students that mostly have problems in reading narrative text for checking the correctness or triangulating the data.

\section{RESULT AND DISCUSSION}

\subsection{Research Results}

The student response results in the questionnaires showed that, there are $25(42.3 \%)$ students having problems in determining main idea, there are $21(35.6 \%)$ students having problems in finding detailed information, there are $31(52.5 \%)$ students having problems in making inference, there are $28(47.4 \%)$ students having problems in identifying reference, and there are $23(38.9 \%)$ students having problems in understanding meaning of words. It means half of the students have problems in making inference $52.6 \%$.

The interview result from English teacher about the main problems students' in reading narrative text at the eighth grade by the English teacher sight is making inference. The researcher also interviews the eighth grade students, 15 students. The interviews result from the eighth grade students show that the students have problems in making inference. Based on the research results of the English teacher and students interviewed above, it can be summarized that the main problems students were making inference.

Based on questionnaire results, there were 31 students having problems in making inference. It means half of the students have problems in making inferences. The results of the interview English teacher and 15 students in eighth grade also showed that the problems encountered by the students were making inferences. To triangulate the data results, the researcher also gave a reading comprehension test to 15 students who were having problems in making inference. The outcomes of the total students' correct and incorrect answers could be seen in Table 2 . 
Table 2 The Total Student Correct and Incorret Answers

\begin{tabular}{|c|c|c|c|c|c|}
\hline No & The Questions & Item Number & $\begin{array}{l}\text { Correct } \\
\text { Answer } \\
\end{array}$ & $\begin{array}{l}\text { Incorrect } \\
\text { Answer }\end{array}$ & $\begin{array}{c}\text { Percentage } \\
\text { (Correct/Incorrect Answer) }\end{array}$ \\
\hline \multirow{5}{*}{1.} & \multirow{5}{*}{ Finding Main Idea } & 5 & 9 & 6 & \multirow{5}{*}{$63 \% / 37 \%$} \\
\hline & & 6 & 10 & 5 & \\
\hline & & 11 & 10 & 5 & \\
\hline & & 16 & 8 & 7 & \\
\hline & & 21 & 10 & 5 & \\
\hline \multirow{5}{*}{2.} & \multirow{5}{*}{$\begin{array}{l}\text { Finding Detailed } \\
\text { Information }\end{array}$} & 1 & 8 & 7 & \multirow{5}{*}{$59 \% / 42 \%$} \\
\hline & & 7 & 9 & 6 & \\
\hline & & 12 & 7 & 8 & \\
\hline & & 17 & 10 & 5 & \\
\hline & & 22 & 10 & 5 & \\
\hline \multirow{5}{*}{3.} & \multirow{5}{*}{ Making Inference } & 3 & 3 & 12 & \multirow{5}{*}{$20 \% / 80 \%$} \\
\hline & & 8 & 2 & 13 & \\
\hline & & 13 & 3 & 12 & \\
\hline & & 20 & 4 & 11 & \\
\hline & & 23 & 3 & 12 & \\
\hline \multirow{5}{*}{4.} & \multirow{5}{*}{ Identifying Reference } & 2 & 6 & 9 & \multirow{5}{*}{$55 \% / 45 \%$} \\
\hline & & 10 & 10 & 5 & \\
\hline & & 15 & 10 & 5 & \\
\hline & & 18 & 8 & 7 & \\
\hline & & 24 & 7 & 8 & \\
\hline \multirow{5}{*}{5.} & \multirow{5}{*}{$\begin{array}{l}\text { Understanding } \\
\text { Meaning of Words }\end{array}$} & 4 & 10 & 5 & \multirow{5}{*}{$65 \% / 35 \%$} \\
\hline & & 9 & 10 & 5 & \\
\hline & & 14 & 12 & 3 & \\
\hline & & 19 & 10 & 5 & \\
\hline & & 25 & 7 & 8 & \\
\hline
\end{tabular}

Based on the outcomes of the total students' correct and incorrect answer, it can conclude that the questions about making inference with items number $3,8,13,20$, and 23 had the lowest correct answer with percentage $20 \%$ and also had the highest incorrect answer with percentage $80 \%$.

\subsection{Discussion}

The research results show most of the student have problems in reading narrative. Their problems are to identify the main idea, to find detailed information, to make inferences, to identify references, and to understand the meaning of words. That result is consistent with [5] who stated that these aspects were considered to be problems that students encounter in understanding the content such as: defining main idea, finding detailed information, making inferences, identifying references, and understanding meaning of words. Those aspects happen because of many factors such as; limited vocabulary and forgetting about the material that has been learned.

The students had problems in determining the main idea with percentage $42.3 \%$, finding detailed information with percentage $35.6 \%$ and making inference with percentage $52.5 \%$. It could have happened due to the students not understanding the text and the students find the words that were not familiar for them. The students also had problems identifying reference with percentage $47.4 \%$. It could have happened due to the students forgetting about pronoun materials that they had learned. The last aspect is that students have difficulties to understand the meaning of words with a percentage $38.9 \%$. It could have happened because the students had limited vocabulary.

This study also shows that the main problems the students is making inference with percentage $52.5 \%$. This case is accompanied by many factors, such as: limited vocabulary, new words, unfamiliar words, and ambiguous words. That result is similar to Reference [2] study stated that reading comprehension issues faced by nonnative speaker students are accompanied by many factors, such as: new words, context information, form text, structure, lack of illustration, tenses, and connecting words. The differences between this study with Reference [2] study are the method and the subject of the study. Reference [2] study uses quantitative and the subject is the students from high school Albania meanwhile this study uses qualitative methods and the subject is the students at the eighth grade of SMPN 2 Kandangan in the academic year 2019/2020.

That result is also similar to Reference [1] study about reading comprehension problems faced by students at a university in Jordan. The results revealed that the students faced many difficulties in the course of learning comprehension, including vague words, odd vocabulary, and restricted to having time to cognitively organize the text. The differences between this study with Qarqez and $\mathrm{Ab}$ Rashid [1] study is the subject of the study. The subject from Qarqez and Ab Rashid [1] study is the students from Yarmouk University meanwhile the subject of this study is the students at the eighth grade of SMPN 2 Kandangan in the academic year 2019/2020. 
In the interview result showed that 15 students have problems in making inferences. The students stated that they have problems in making inference because they do not understand the text and find new words. It means the students have problems with vocabulary and new words. That result is similar with Reference [4] study stated that his research finding revealed that the students were weak at vocabulary, finding orientation, complication, resolution, and reorientation. The differences Sarwo [4] study with this study is the instrument to collect the data. Sarwo [4] study uses reading test as the instrument meanwhile this study uses questionnaire and interview as the instrument.

The researchers used a reading comprehension test. The researcher gave the test to 15 students who had problems in making inference. The outcomes of the total students' correct and incorrect answers showed that the questions about making inference with items number $3,8,13,20$, and 23 had the lowest correct answer with percentage $20 \%$ and also had the highest incorrect answer with percentage $80 \%$. One of the narrative stories that appear in the 8th-grade text is the story of Toba Lake. Lake Toba occurs as a result of a large earthquake accompanied by continuous heavy rain in other words environmental factors that make Lake Toba occur even though according to the story all of this happened because the man broke his promise. Based on this story, can we discover that environmental factors affect legend although there are some people who believe that it is not natural factors but mystical or magical abilities.

\section{CONCLUSION AND SUGGESTIONS \\ 4.1 Conclusion}

The researchers concluded that the problems faced by the students' in reading narrative text were determining main ideas, finding detailed information, making inference, identifying reference, and understanding meaning of words. There were 25 students had problems in determining main idea, there were 21 students had problems in finding detailed information, there were 31 students had problems in making inference, there were 28 students had problems in identifying reference, and there were 23 students had problems in understanding meaning of words. It means half of the students had problems in making inference.

\subsection{Suggestions}

Based on the conclusions above, the researcher would like to suggest as follows:

a. The students should read a variety of book stories with different levels so that they increase their vocabularies. It is also suggesting to the students to practice more to answer reading comprehension tasks. b. To English teacherare suggested to use cooperative learning strategy and also it is suggested to teach the students the technique to find the vocabulary meaning by using clues from the context. Then, the English teacher should teach reading skills especially to the students and also give reading comprehension tasks in order to give the student knowledge about reading comprehension skills.

c. To further researchers, it is proposed that different instruments be applied to the other research studies.

\section{REFERENCES}

[1] M. Qarqez and R. Rashid, "Reading Comprehension Difficulties among EFL Learners: The Case of First and Second -Year Students at Yarmouk University in Jordan," Arab World English J., vol. 8, no. 3, pp. 421-431, 2017, doi: 10.24093/awej/vol8no3.27.

[2] I. Shehu, "Reading Comprehension Problems Encountered by Foreign Language Students, Case Study: Albania, Croatia,” Acad. J. Interdiscip. Stud., no. October, 2015, doi: 10.5901/mjss.2015.v4n1s1p91.

[3] M. L. Pang, E. E., Muaka, A., Bernhardt, E. B., and Kamil, "Teaching Reading," Chicago: University of IIIions at Chicago, 2003.

[4] Sarwo. Analysis on the Students Problems in Comprehending Narrative Texts (Doctoral dissertation, Tanjungpura University).

[5] C. Nuttal, Teaching Reading Skill in a Foreign Language. London: Heinerman Educational Books, 1982.

[6] U. Romdoni, Improving Students' Reading Comprehension Skill Using Fable Story Text. JEET, Journal of English Education and Technology. 2020 Feb 1;1(02):135-53.

[7] N.K., Duke, P.D., Pearson, S.L Strachan,. and A.K., Billman. Essential elements of fostering and teaching reading comprehension. What research has to say about reading instruction, 4, pp.286-314. 2011.

[8] A Mangen, B.R Walgermo, K. Brønnick. Reading linear texts on paper versus computer screen: Effects on reading comprehension. International journal of educational research. 2013 Jan 1;58:61-8.

[9] Mitra. Students' Problem In Narrative Text: What Deals And What To Do?. Humanitatis: Journal of Language and Literature. 2017 Dec 30;4(1):86-107.

[10] J.E. McPeck Critical thinking and education. Routledge; 2016 Sep 13. 